\title{
Impact of Climate Change on Surviving of Phlomis aurea as an Endemic Species Growing in Southern Sinai, Egypt
}

\author{
Marwa M. Serag, Abdel Raouf A. Moustafa* and Sara S. Qiqa \\ Botany Department, Faculty of Science, Suez Canal University, 41522 Ismailia, Egypt
}

\begin{abstract}
The changing climate globally is one of the most important influences that affect distribution patterns and phenology of plants. Global average temperatures have increased by more than $2^{\circ} \mathrm{C}$. In the last century while precipitation patterns have plummeted dramatically. Phlomis aurea is a perennial species, endemic to South Sinai in Egypt; it grows in basins and gorge habitats which increase its ability to survive the natural arid environment of South Sinai. Phlomis aurea has a significant ecological and medicinal feature; it has a role in pollination due to the lipped flower it carries forming an arrival stage for honey bees, while medicinally, it has anti-inflammatory, antimicrobial, cytostatic and immunosuppressant characteristics. Moreover, it's famous for antidiabetic activity in folk medicine. According to the IUCN, Phlomis aurea is a threatened species in Egypt that needs firm conservation plans considering the changing climate as a threat to biodiversity loss. The following review aims at investigating the current status of Phlomis aurea in Egypt and its vulnerability to climate change incidence taking over the globe. In conclusion, it's expected that, Phlomis.aurea would be highly resistant to increased drought; however, on the long run and with harsher climate change scenarios there could be a severe decline in the population unless precautions have been followed.

Keywords: Impact of climate change, Phlomis aurea, Endemic species, Folk medicine, Seed germination, Phenology, Conservation.
\end{abstract}

\section{INTRODUCTION}

Climate is one of the basic factors that affect the organism life cycle like plant germination and flowering. It can alter the habitat and food resources of the organism, can lead to migration of organism and thus affect negatively on the biodiversity population size and ecosystem (Hui, 2013). Global climate change is extremely considered as one of the fundamental factors causing biodiversity loss. Over the past 100 years, the global average temperature has expanded by around $0.6^{\circ} \mathrm{C}$ and is projected keep on rising at a quick rate (Root et al., 2003), the continuous increasing temperature will affect negatively on plant biodiversity and on the ecosystem in general.

Unlike climate change, an important factor influencing wildlife in general and plant life and its diversity, in particular, is an event that occupies the world these days because of its future potential to threaten the environment, thus assessing the climate change and its influence on the plant should take in consideration in any conservation program. In order to establish an effective conservation program for a plant species, we should have enough knowledge of its biology and ecology.

The importance of nature preservation methodology is the foundation and up keeping with a framework or system of ensured zones, yet it is not enough to change the world (Huntley, 1999). Providing a database on the target species is the most important step in any conservation program (Shaltout et al., 2015). The process of gathering this information is sometimes referred to as an Eco-geographical survey or study (Maxted et al., 1995), which is the driven of all protection issues and a key necessity in the advancement of any preservation meth- odology (Ouédraogo, 1997). The protection of endemic species is a worldwide need; endemic species are regularly the most defenceless against anthropogenic dangers because of their exceptional transformative history and similarly low population size.

Thus, this review article focuses on the status of phlomis aurea as an endemic species amid the dramatic effect of climate change with some suggestions and recommendations to conserve its population.

\section{Morphology}

Phlomis.aurea Decne (its Vernacular name is Awarwar) is a wild golden woolly perennial species; It is characterized by its yellow colored petals, shrubby habit and the medium size that vary from 24-36 tall. The shrub grows to $60-90 \mathrm{~cm}$ in height and $90-120 \mathrm{~cm}$ in width (Photo.1).

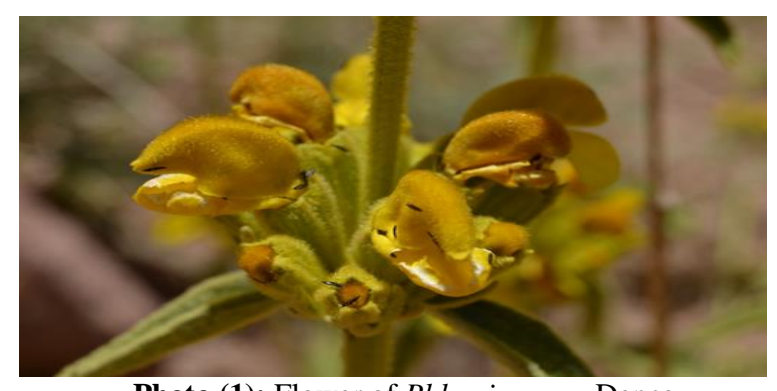

Photo (1): Flower of Phlomis aurea Dence.

\section{Geographical distribution and Ecology}

Genus Phlomis (Lamiaceae) comprises about 100 species in the world (Mediterranean region to central Asia and China). In Egypt, two Phlomis species occur, Phlomis aurea Decne and Phlomis floccosa D. Don 
(Täckholm, 1974; Boulos, 2002). Phlomis aurea Decne is a wild golden-woolly perennial species; it is a rare and endangered endemic species restricted to the high altitudes in the southern Sinai Peninsula (Fig. 1) (Boulos, 2008), especially in Saint Catharine and Mousa mountains (El-Hadidi and Hosni, 2000).

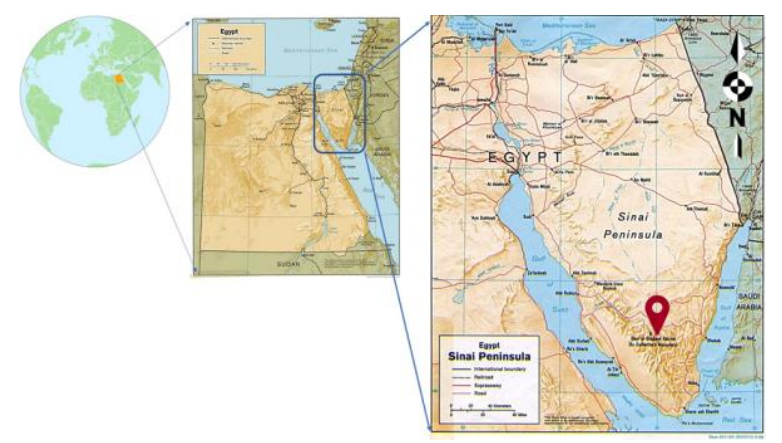

Figure (1): Map shows the geographical distribution of Phlomis aurea in Egypt.

\section{Phenology}

Vegetative growth starts slowly in October, maximizes in April and declines in June. Flower budding starts slowly in April, then maximizes and declines in May. Flowering starts slowly in May, maximizes and declines in June (Fig. 2). Seed shedding starts and increases progressively through July-August but maximizes in September, then plants keep vegetative from October through March.

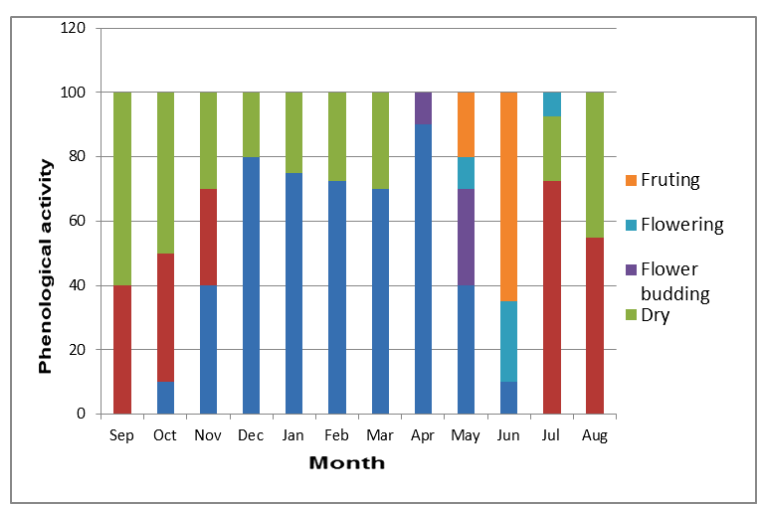

Figure (2): Phenological aspects of Phlomis aurea (Ramadan et al., 2009).

\section{Catherine Mountain}

Is the highest peak in Egypt (2641 m.s.l.), located in the center of South Sinai and represents a series of mountains at different elevations. The rock sorts are acid plutonic and volcanic rocks. The area of Saint Catherine Mountain has two main deep gorges; Shaq Mousa, and Garagneia, plus five main Wadis: Wadi ElIsbaiya, Wadi ElRutig, Wadi ElArbaeen, Wadi Zawatee, and Wadi Razana (Mosaad, 2017).

\section{Mousa`s mountain}

Mountain Mousa (2285 m.a.s.l.) is one of the holiest, historical, and respectful places in Sinai and the whole world, located on the eastern side of Mountain Catherine. The rock sorts are mainly granite with smooth faced outcrops. The mountain is characterized by numerous tremendous gorges covered with large boulders.

The geomorphology of the mountain is one of the most fantastic formations which includes; terraces, curved slopes, depressions, and small plains or Farsh such as Farsh Mousa. Mountain mousa has two main Wadis acting as boundaries: Wadi El-Faraa and Wadi El-Deir (Mosaad, 2017). Generally, Bedouins in Saint Catherine are using the dry individuals for fuel, while they cannot use the green individuals directly because it has hairs that attack the skin and eyes and cause itching and allergies (Shaltout et al., 2004).There are increasing threats facing its populations, as it is subjected to severe overcutting and uprooting (for fuel), as well as disturbance through unmanaged human activities and increased drought (Moustafa and Abd El-Wahab, 2013). Phlomis aurea is quite resistant to drought; it likes the position in full sunlight. It prefers soils of neutral to alkaline (pH 6.6-8.5), and it is attractive to bees, butterflies, and birds.

In 2015, Shutout recorded the associated taxa with Phlomis aurea populations; 63 species related to 56 genera and 30 families. Compositae had the highest contribution $(11$ species $=17.5 \%)$, followed by Labiatae (10 species $=15.9 \%$ ), while the perennials were 55 species, while the annuals were 3 species, and biennials were 5 species.

The high percentage of perennials $(87.3 \%)$ may be related to their ability to resist the drought, salinity and sand accumulation (Barakat et al., 2014). The population of Phlomis aurea in the basin had the second highest density (after the gorges) associated with the highest cover and size index (Fig. 3); this might be credited to adequate dampness and nutrients contrasted and alternate living spaces, as it was a catchment region; got an extra measure of water and nutrients from the neighbouring raised regions (Moustafa et al., 1993).

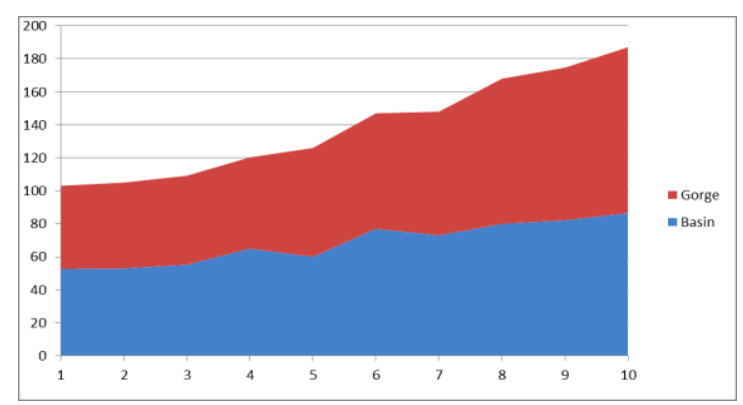

Figure (3): The Population density of Phlomis aurea in gorge and basin habitat.

\section{Role in pollination}

Lipped flowers typically belong to the Sage Family (Lamiaceae) or the Pea family (Fabaceae). These are specific blooms that by and large have a close association with honey bees or single honey bees. The lip at 
the front of the bloom is the arrival stage; the honey bee at that point pushes its head into the flower to get at the nectar which is discharged at the back of the flower. In the meantime, the plant places pollens on to the back of the honey bee's thorax (neck area). It is hard for the honey bee to expel pollen from this spot, and along these lines the honey bee conveys pollen from flower to flower and guarantees fertilization. Lipped blossoms, for example, those in the pea family (Fabaceae) and Sage family (Lamiaceae) take after this example of specialization. These lipped blooms normally have an 'arrival stage' where a honey bee or Anthophora honey bee can arrive before it enters the blossoms. Increasing pollination will provide a food resource for local community and this will make them keen to avoid misusing of Phlomis aurea and maintain its population to increase honey production.

\section{Seed germination}

The shape and size $(8 \times 4 \mathrm{~mm})$ of Phlomis area seeds (Photo 2). The average seed weight is about $0.00315 \mathrm{~g}$ and one gram includes about 317.5 seeds. Each fruit contains four seeds (nutlets), based on naked eye examination and the Tetrazolium viability test, two different types of seeds were recognized, the first type is large, fat and mature, while the second type is thin and immature (just as seed testa). Immature ratio amounts to about $98 \%$ of the total seed setting in some populations (Zaghloul, 1997).

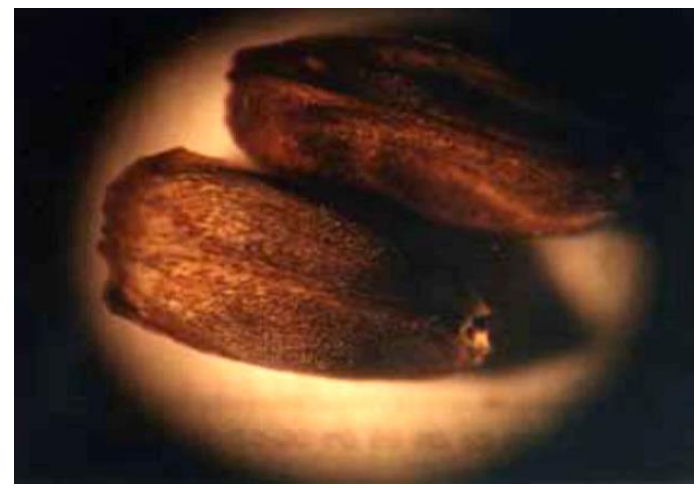

Photo (2): Seeds of Phlomis aurea (Ramadan et al., 2009).

\section{Soil seed bank}

The germination behaviour of Phlomis aurea seeds showed its highest ratio $(66 \%)$ in dark incubator at a constant temperature $\left(15^{\circ} \mathrm{C} \pm 2\right)$, without seed pretreatment. It was evident also that the germination ratio (32\%) under light condition was relatively better than those under shade (19\%) and in darkness (12\%) (Zaghloul, 1997).

\section{Conservation status}

The threatened species in Sinai according to the IUCN Red List Categories were 51 species: 13 endangered, 14 vulnerable, 20 rare and 4 indeterminate. IUCN recorded taxa ought to get high need in any protection program (El-Hadidi and Hosni, 2000). Phlomis aurea is an uncommon and imperiled endemic species possessing high heights at the southern Sinai Peninsula, Egypt (Boulos, 2002; El-Hadidi and Hosni, 2000), and can adjust numerous natural factors that prompt its distribution in this region (Abd El-Wahab et al., 2004). Numerous bushes and trees of the arid regions are of structural and economic importance (Crisp and Lange, 1976). They assumed a paramount part in soil insurance and stabilization against movement by wind or water, provide a source of forage for animals and fuel for local inhabitants (Thalen, 1979). Phlomis aurea is threatened by two central points; over cutting and uprooting, the pressure of livestock on Phlomis aurea increases as a result of the expansion in Bedouin, population (Shaltout et al., 2004). Distribution and abundance of a plant species within a particular climatic zone are determined.by environmental factors, especially soil conditions, interactions with other species; and dispersal. Survivorship and fertility appear to be primarily determined by the size and the developmental stage, rather than an age of individuals within a plant population (Silver-town, 1981, Werner and Caswell, 1977; Galal, 2011). Along these lines, the status of a plant population will be reflected by its thickness and size structure, in 1985 Weiner suggested that measure contrasts might be caused specifically or through differences in development rates because of age contrasts, hereditary variety, heterogeneity of assets, herbivory, and competition.

\section{Medicinal uses \\ Folk medicine}

In Egyptian people medication, the plant is utilized as antidiabetic (Watt and Breyer, 1962). Diverse classes of glycosides including diterpenoids (Katagiri et al., 1994; Tanaka et al., 1983; Tanaka et al., 1985), iridoids (ElNaggar and Beal, 1980; Çalis et al., 1991), phenylpropanoids (Saracoglu et al., 1995 and Çalis et al., 1991), phenylethanoids (Saracoglu et al., 1998) and flavonoids (Tomas et al., 1986 and El-Negoumy et al., 1986) had been recognized from genus Phlomis. Many of the phenylpropanoids isolated from genus Phlomis showed significant biological activities, e .g. cytotoxic anti-inflammatory immunosuppressant and anti-microbial effects (Saracoglu et al., 1995). Only flavonoids had been described from Phlomis aurea (El-Negoumy et al., 1986). Various Phlomis species (Lamiaceae) have been utilized in folk medicine as stimulants, anticough products, and to treat gastric, intestinal as well as abdominal pains, as a tonic, sedative, carminative and astringent. Various activities such as anti-nociceptive, antiulcer genic and antioxidant, anti-genotoxic, anticancer and anti-inflammatory.

\section{Impact of climate change}

Over the last 10,000 years, the climate in Egypt has changed many times. According to temperature data analysis for the last 50 years, the temperature shows an 
average increase with decreasing rainfall which is causing severe droughts affected negatively on the population dynamics of many plant and animal species. South Sinai is characterized by an arid to extremely arid climate with long hot rainless summer and mild winter (Migahid et al., 1959; Zohary, 1973; Issar and Gilad, 1982; Danin, 1983; and 1986). Precipitation occurs mostly in winter. The climate is influenced by the Mediterranean and by the orographic impact of the high elevation of the mountains in southern Sinai. The tropical influence is prominent along the Gulf of Suez and the Gulf of Aqaba (Danin, 1986). Due to the wide range of altitude, South Sinai is characterized by a wide range of variation in air temperature (Moustafa et al., 1999).

Saint Catherine is the coolest area in Sinai and Egypt as a whole due to its high elevation. During the period from 1979 to 1992, the lowest monthly mean minimum temperature was recorded in January and February $\left(1.4^{\circ} \mathrm{C}\right)$, while the highest mean maximum temperature in June and July 30.8 and $31.8^{\circ} \mathrm{C}$, respectively (Abd ElWahab, 2003). According to Cedar Lake Ventures (2017). In Saint Catherine, the summers are long, warm, arid, and clear and the winters are chilly, dry, and mostly clear. Over the course of the year, the temperature typically varies from $-2^{\circ} \mathrm{C}$ to $27^{\circ} \mathrm{C}$ and is rarely below $-5^{\circ} \mathrm{C}$ or above $29^{\circ} \mathrm{C}$. The warm season lasts for 4 months, from May 25 to September 24, with an average daily high temperature above $23^{\circ} \mathrm{C}$. The hottest day of the year is August 6, with an average high of $27^{\circ} \mathrm{C}$ and low of $16^{\circ} \mathrm{C}$.

The cold season lasts for 3 months, from December 1 to March 8 , with an average daily high temperature below $13^{\circ} \mathrm{C}$. The coldest day of the year is January 17 , with an average low of $-2^{\circ} \mathrm{C}$ and high of $10^{\circ} \mathrm{C}$. Warming straight forwardly influences the rate of plant breath, photosynthesis, and other biogeochemical forms. For example, improved $\mathrm{CO}_{2}$ concentration can increase photosynthetic rate, particularly for plants becoming under a warm and dry condition, for example, C3 plants. Normally, plants have their own specific mechanism to endure a specific level of expanded temperature. As soil temperature increase, the deterioration rate of will increase, and accordingly supplement mineralization and accessibility for plants. In this manner, the communication and diverse blend impact of rising $\mathrm{CO}_{2}$ focus and temperature are dictated by soil properties, water, mineral and nutrients accessibility and so forth, thus the normal reaction of plants in various conditions and atmosphere fluctuation can be either positively or negatively influenced (Amedie, 2013).

All cultures from ancient times to the present day have used plants as a source of medicines. Today, according to the World Health Organization (WHO), as many as $80 \%$ of the world's people depends on tradetional medicine for their primary health care needs. The greater part of traditional therapy involves the use of plant extracts or their active principles. The medicinal species that reside in natural areas have received increasing scientific and commercial attention in the recent years; Phlomis plants have been mentioned since the times of Dioscorides as natural cures and utilized as a part of customary prescription for the treatment of different conditions, for example, diabetes, hemorrhoids, gastric ulcer, aggravation, and the mending of wound (Amor et al., 2009). These days, some Phlomis species are consumed as a tea in some Mediterranean cultures (Couladis et al., 2003; Karali et al., 2016 and López et al., 2010).

The effects of climate change have become obvious in the natural environment over the last 30 years, together with other threats like habitat destruction, fragmentation, disturbance and loss in biodiversity (Lepetz et al, 2009). Surveying the effects of climate change will be a key assignment in developed and in developing countries due to numerous reliant physical, biological and chemical processes are progressing in the earth and human frame works (Amedie, 2013). In regions where climatic change may lead to warmer and drier conditions, mountain vegetation could suffer more as a result of increased evapotranspiration (Elkeblawy, 2014). Another point of view accepting the idea of; the higher the temperature the higher the biodiversity, recently by a team of ecologist from German Centre for integrative biodiversity(iDiv), they discover that number of Nematodes increasing with high temperature in polyculture plot with different plant species while their number declined in monoculture plot (Thakur et al., 2017).

\section{DISCUSSION}

The protection of endemic species is a worldwide need; especially under the recent climate change circumstances, endemic species are the most defenceless against anthropogenic threats because of their unique evolutionary history and generally low population estimate. According to the (EEAA), total (GHC) emissions in Egypt has increased from 1933 million tons of eq. $\mathrm{CO}_{2}$ in the year 2000 to 318.2 million tons of eq. $\mathrm{CO}_{2}$ in 2010 with the most contribution of the energy, industry, agriculture and waste sectors (Nakhla et al., 2013). However, Egypt's contribution to the global greenhouse gas (GHG) emissions is only $0.57 \%$ and it is considered a non-annex I country which means that there is no urgently needed plan for $\mathrm{CO}_{2}$ emission reduction under the Kyoto protocol (Selim, 2009; United Nations Framework Convention on Climate Change, 2010). Thus, the climate change danger specially in remote destinations such as Saint Cathrine would be rather minimal, not that we under estimate the danger but hopefully there are no signs of further deterioration in the environmental conditions, on the other hand, Phlomis aurea is adaptive to arid environment naturally, on morphological, physiological and ecological levels. As it was noticed that leaves sprouting in winter were larger in size, thinner and carrying stellate hairs on both sides, while, those sprouting in spring were smaller in size and covered on both sides with a thick layer of 
stellate hairs which is a typical drought resistant strategy to hold in more moisture (Ramadan et al., 2009).

In addition, the plant can choose to grow in the form of bushes in gorge habitats and basins that act as reservoirs for nutrients and water collected from precipitations and other sources of irrigation (Moustafa and Zaghloul, 1993). Phlomis aurea are stable, uniform, reliable, reprodu-cible and largely independent of age and environmental fluctuations (Sammour, 2014). Phlomis aurea is a high polymorphic species, it was suggested that the micro-habitat distribution of Phlomis. aurea have caused either epigenetic changes or mutations which were in favour to its high adaptability and stress resistance (El-Sadek et al., 2017). From the past literature, Phlomis aurea is an endangered plant that is highly resistant to drought and harsh environmental conditions; it's endangered mainly due to over grazing and frequent uprooting by the local community in Saint Cathrine (Abd El-wahab et al., 2004). Climate change in a stressing issue globally and regionally however the microhabitat distri-bution of Phlomis aurea have provided enough protect-tion for the species to tolerate and withstand slowly changing environment, however, further monitoring will be needed on the long run as the problem of climate change is persistent.

\section{CONCLUSION AND RECOMMENDATIONS}

Phlomis aurea is an important plant ecologically, medicinally and economically, it is characteristic to arid and dry lands and contains several bioactive substances that are widely used in the pharmaceutical industries and folk medicine and thus, it is an endangered plant that needs urgent restoration. It's strongly recommended to work on a strict conservation plan for Phlomis aurea to rather protect it from the anthropogenic stressors as well as environmental stressors. The Seed bank is one of the known strategies along with increasing public awareness and involving the local communities of south Sinai in the environmental work (Ramadan et al., 2009). In addition, increasing the area of the protected areas at mid- to high altitude in the Southern Sinai to grant further protection in zones with the highest density of endemism is recommended (Shaltout et al., 2015).

Investigating any potential threat that might cause habitat loss or degradation. Laws and legislation that regulates the conservation process with the help of the administrative authorities of the country are urgently in need. Using plant parts for research purposes should be limited or controlled not to reach the exploitation levels, constructing gene banks of the species from different habitats and destinations. Further testing of the drought tolerance pathways and drought avoidance strategies of the plant should be done in the laboratory for more understanding of its physiological characteristics under different scena-rios of climate change and thus more appropriate future protection plans.

\section{ACKNOWLEDGEMENT}

The authors are grateful to Dr. Samira Mansour and the staff of SATIS project and would like to thank them for supporting this work.

\section{REFRENCES}

ABD EL-WAHAB, R.H. 2003. Ecological evaluation of soil quality in South Sinai, Egypt. Ph.D. Thesis, Botany Department, Faculty of Science, Suez Canal University, Ismailia.

ABD EL-WAHAB, R.H., M.S. ZAGHLOUL, AND A.A. MOUSTAFA. 2004. Conservation of medicinal plants in St. Catherine protectorate, South Sinai. I Evaluation of ecological status and human impact. In: Proc. of 1st Inter. Conf. on Strat. of Egypt. Herb., pp. 231-251.

AMEDIE, F. A. 2013. Impacts of Climate Change on Plant Growth, Ecosystem Services,Biodiversity and Potential Adaptation Measures.

AMOR, I.LB., J. BOUBAKER, M. Ben Sgaier, I. Skandrani, W. Bhouri, A. Neffati, S. Kilani, I. Bouhlel, K. Ghedira, L. Chekir-Ghedira. 2009. Phytochemistry and biological activities of Phlomis species. J Ethnopharmacol 125:183-202.

BARAKAT N.A.M., A.M.A. EL-GAWAD, V. LAUDADIO, H.F. KABIEL, V. TUFARELLI, AND E. CAZZATO. 2014. A contribution to the ecology and floristic markers of plant associations in different habitats of Sinai Peninsula, Egypt. Rend. Fis. Acc. Lincei 25: 479-490.

BOLOUS, L., 2008. Flora and vegetation of the deserts of Egypt. Fl. Medit. 18: 341-359.

BOULOS, L., 2002. Flora of Egypt. Vol. 3: Verbenaceae- Compositae. Al-Hadara Publishing, Cairo, Egypt.

COULADIS, M., O. TZAKOU, E.VERYKOKIDOU, C. HARVALA. 2003. Screening of some Greek aromatic plants for antioxidant activity. Phytother Res 17:194-195.

CRISP, M.D., AND R.T. LANGE. 1976. Age structure, distribution and survival under grazing of the aridzone shrub Acacia burkitii. Oikos 27: 86-92.

DANIN, A. 1983. Desert vegetation of Israel and Sinai. Jerusalem: Cana Publishing House.

DANIN, A.1986. Flora and vegetation of Sinai. Proceedings of the Royal Society of Edinburgh, 89 (B): 159-168. Ecological status and human impact In: Proc. of 1st Inter Conf on Strat of Egypt Herb., pp. 231-251.

EL-HADIDI, M.N., AND H.A. HOSNI. 2000. Conservation and threat In El-Hadidi M.N.(ed.), Flo-

EL-KEBLAWY, A. 2014. Impact of Climate Change on Biodiversity Loss and Extinction of Endemic plants of Arid Land Mountains. J Biodivers Endanger Species 2: 120. doi: 10.4172/2332-2543.1000120

EL-NAGGAR, L., AND J. BEAL. 1980. Iridoids. Revi- 
ew. Journal of Natural Products 43: 649-707.

EL-NEGOUMY, S.I., M.F. ABDALLA AND N.A.M. SALEH. 1986. Flavonoids of Phlomis aurea and phlomis. occosa Phytochemistry 25; 772-774.

EL-SADEK, L.M., G.E. EL-BADAN, AND H. A. SHABANA. 2017. Genetic Diversity of the Endemic Species Phlomis aurea Decne. In Southern Sinai, Egypt. The 7th Inter Conf. "Plant and Microbial Biotech. and their Role in the Development of the Society"pp. $147-159$.

GALAL, T.M. 2011. Size structure and dynamics of some woody perennials along elevation gradient in Wadi Gimal, Red Sea coast of Egypt. Flora 206, 638-645.

HUI. D., 2013. Global Climate Change and Biodiversity: Issues and Future Research. J Biodivers Endanger Species 1: 1-2.

HUNTLEY. B., 1999. Species distribution and environmental change In Maltby E, Hodgate M Acreman.M. and WeirA. (Eds.). Ecosystem management Questions for science and society. Royal Holloway, University of London, Institute for Environmental Research, Egham: 115-129.

ISSAR, A., AND D. GILAD. 1982. Ground water flow systems in the arid crystalline province of Southern Sinai. J. Hydrogeol. Sci., 27 (3): 309-325.

KARALI, DEBORA, ET AL. 2016. "T cell regulation by Phlomis lanata protein extracts in mice. "Pharmaceutical biology 54.2 2016: 207-214.

KATAGIRI, M., K. OHTANI, R. KASAI, K. YAMASAKI, C. R. YANG, AND O. TANAKA, 1994. Diterpenoid glycosyl esters from Phlomis young- husbandii and Phlomis. medicinalis roots. Phytochemistry 35, 439-442.

López V., A.K. Jäger, S. Akerreta, R.Y. CAVERO, M.I. CALVO. 2010. Antioxidant activity and phenylpropanoids of Phlomis lychnitis L.: A traditional herbal tea. Plant Foods Hum Nutr 65:179-85

LEPETZ. V., M. MASSOT. D.S. SCHMELLER. AND J. CLOBERT. 2009. Biodiversity monitoring some proposals to adequately study species' responses to climate change. biodiversity conservation. 18: 31853203.

MAXTED, N., VAN M.W. SLAGEREN AND J.R. RIHAN. 1995. Ecogeographic surveys. In: Guarino L., Ramanatha Rao V. and Reid R. (eds), Collecting plant genetic diversity. CAB International, Wallingford: 255-285.

MIGAHID, A.M., A. EL-SHAFEI, A.A. ABDELRAHMAN AND M.A. HAMMOUDA. 1959. Ecological observations in Western and Southern Sinai. Bull. Sco. Geogr. d'Egypte 32: 166-206.

MOSAAD, D. F. 2017. Autecology of a threatened medicinal plant species: Chiliadenus montanus.

MOUSTAFA, A., RAMADAN, M.S. ZAGHLOUL, AND M.A. HELMY. 1999. Environmental factors affecting endemic species, species richness and diversity in Saint Catherine Protectorate, South
Sinai, Cairo, Egyptian Journal of Union of Arab Biologists 9 (B): 419-446.

MOUSTAFA, A., AND M.S. ZAGHLOUL. 1993. Environmental factors affecting the distribution of plant species in gorge habitats, South Sinai, Egypt.

MOUSTAFA. A.A. AND R.H. ABD EL-WAHAB 2013. Soil fertility in South Sinai, Egypt. Lap Lambert Academic Publishing, Sarrebruck, 165 p.

NAKHLA, D.A., M.G. HASSAN AND S. EL HAGGAR. 2013. Impact of biomass in Egypt on climate change, Natural Science, Vol.5, No.6, 678684.

OUÉDRAOGO A. S. 1997. Conservation and use of forestgenetic resources. In: Proceedings of the XI World Forestry Congress, Antalya, 13-22 October 1997. FAO, Rome: 173-188 p.

ra Aegyptiaca. Vol I, part 1. Palm Press, Cairo: 151.

RAMADAN. AA., A.A. MOUSTAFA, M. S ZAGHLOUL, AND M.A. HELMY., 2009. Conservation of Three Endangered Species at St. Catherine Protectorate, South Sinau, Egypt. CATRINA, 4 (1): 53-64.

ROOT T.L., J.T PRICE, K.R. HALL, S.H. SCHNEIDER, AND C. ROSENZWEIG 2003. Fingerprints of global warming on wild animals and plants. Nature 421: 57-60.

SAMMOUR, R.H. 2014. Cultivars identification based on biochemical markers. Research and Reviews in BioSciences, 8(9): 347-358.

SARACOGLU I., M. INOUE, I. ÇALIS, Y. OGIHARA. 1995. Studies on constituents with cytotoxic and cytostatic activity of two Turkish medicinal plants: Phlomis armeniaca and Scutellaria salviifolia. Biol Pharm Bull 18: 1396-1400.

SARACOGLU, I., K. KOJIMA, U.S. HARPUT AND Y. OGIHARA. 1998. A new phenylethanoid glycoside from Phlomis pungens Willd. var pungen. Chemical Pharmaceutical Bulletin 46, $726 \pm 727$. sci.Adv.3, e1700866.

SELIM, T.H. 2009. Egypt's carbon emissions and the kyoto protocol. Egypt, energy and the environment. Adonis and Abbey Ltd.

SHALTOUT K. H., D. A. AHMED. AND $\mathrm{H}$. SHABANA. 2015. Population structure and dynamics of the endemic species Phlomis aurea Decne in different habitats.

SHALTOUT K.H., S.Z. HENEIDY, Y.M. ALSODANY, A.M. MARIE, E.M. EID, M.Z. HATIM AND A.E. EL-GHARAIB. 2004. Floristic survey of the mountainous Southern Sinai: Saint Katherine Protectorate Conservation and Sustainable Use of Medicinal Plants in Arid and Semi-arid Ecosystems Project, Egypt. Final Report, GEF and UNDP, Project No: 12347/12348.

SHALTOUT, K. H., D. A. AHMED. AND H. SHABANA. 2015. Distribution of the associated species with Phlomis aurea Decne along an elevation gradient in Southern Sinai, Egypt. 
SILVERTOWN, J.W. 1981. Introduction to Plant popuPopulation Ecology. Longman, London.

TANAKA, T., O. TANAKA, Z.W. LIN, AND, J. ZHOU AND H. AGEA. 1983. Sweet and bitter glycosides of the Chinese plant drug, Bai-Yun-Shen (roots of Salvia digitaloides). Chemical Pharmaceutical Bulletin 31, 780-783.

TANAKA, T., O. TANAKA, Z.-W. LIN,. AND, J. ZHOU. 1985. Sweet and bitter principles of the Chinese plant drug, Bai-Yun-Shen: revision of the assignment of the source plant and isolation of two new diterpene glycosides. Chemical Pharma-ceutical Bulletin 33, 4275-4280.

THAKUR, M. P., D. TILMAN, O. PURSCHKE, M. CIOBANU, J. COWLESS, F. ISBELL, P. D. WRAGG, AND N. EISENHAUER. 2017. Climate warming promotes species diversity, but with greater taxonomic reduncy in complex environments.

THALEN, D.C.P. 1979. Ecology and Utilization of Desert Shrub Rangelands in Iraq. Junk Publ., The Hague.

TOMAS, F., J.L. NIETO, F.A.T. BARBERAN, AND F. FERRERES, 1986. Flavonoids from Phlomis lychnitys. Phytochemistry 25, 1253-1254.

TÄCKHOLM, V. 1974. Students' Flora of Egypt. $2^{\text {nd }}$ editon, Beirut: Cairo University.

UNITED NATIONS FRAMEWORK CONVENTION ON CLIMATE CHANGE. 2010. Egypt second national communication.

WATT, J., AND M. BREYER. 1962. Medicinal and Poisonous Plants of Southern and Eastern Africa. Livingstone, London.

WEINER, J. 1985. Size hierarchies in experimental populations of annual plants. Ecology 66, 743-752.

WERNER, P.A., AND H. CASWELL. 1977. Population growth rates and age vs. stage distribution models for teasel (Dipsacus sylvestris Huds.). Ecology 58, 1103-1111.

ZAGHLOUL, M. S. 1997. Ecological studies on some endemic plant species in South Sinai, Egypt. M SC Thesis, Botany Department, Faculty of Science, Suez Canal University, 279 p.

ZOHARY, M. 1973. Geobotanical foundations of the Middle East. Gustav Fischer Verlag. 739 pp. Stüttgart.

ÇALIS, I., A.A. BASARAN, I. SARACOGLU, O. STICHER AND P. RUE EDI. 1991. Phlinosides D and E, phenylpropanoid glycosides and iridoids from Phlomis linearis. Phytochemistry 30, 3073-3075.

\title{
تأثير التغير المناخي على بقاء نبات ال phlomis aurea كنوع مستوطن في جنوب سيناء ، مصر
}

\author{
مروة محمد سراج، عبد الروؤف مصطفى، سارة صبحي

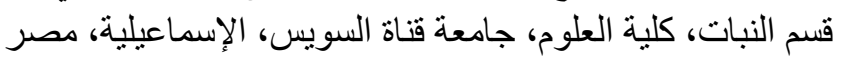

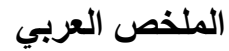

المناخ المتغير عالمياً هو واحد من أهم المؤثرات التي تؤثر على أنماط توزيع و phenology للنباتات. زاد متوسط درجات

الحرارة العالمية بأكثر من درجتين مئويتين.في القرن الماضي، في حين انخفضت أنماط هطول الأمطار بشكل كبير. يعد من الأنواع المستوطنة في جنوب سيناء في مصر. ينمو في الأحواض و الموائل الخانقة التي تزيد قدرتها على البقاء على قبد الحياة في البيئة الطبيعية القاحلة في جنوب سيناء. Phlomis aurea له ميزة بيئية وطبية كبيرة؛ حيث له دور في التلقيح بسبب الزهرة المليئة بالشحوم، وهو يحمل في طياته مرحلة وصول لنحل العسل، في حين أنه له دواء مضاد للالتهابات ومضاد للمبكروبات ومقوي للمناعة. علاوة على ذلك، تشتهر بالنشاط المضاد لمرض السكر في الطب الشعبي.وفقا لـ IUCN،

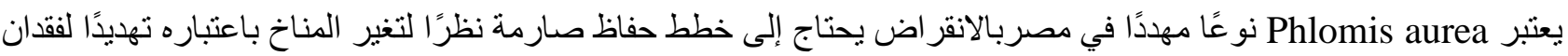
التنوع البيولوجي. وفي هذا المقال نسلط الضوء علي الوضع الحالي لله Phlomis aurea في مصر وتأثره بتغير المناخ. ومن المنوقع أن يكون Phlomis aurea مقاومًا جيد للجفاف المتزايد؛ ومع سيناريوهات تغير المناخ الأكثر قسوة يمكن ان يحدث له له اندثار حاد في ويهدد بالانقر اض وهذا في عدم اتباع الاحتياطات اللازمة لبقاءو الحفاظ علي النبات. 